\title{
KERÁMIA GÖMBHÉJJAL TÖLTÖTT SZINTAKTIKUS FÉMHABOK TÖRÉSMECHANIKAI VIZSGÁLATA
}

\section{FRACTURE MECHANICS TESTING OF CERAMICS HOLLOW SPHERES FILLED SYNTACTIC FOAMS}

\author{
Katona Bálint ${ }^{1}$, Szlancsik Attila ${ }^{1}$, Orbulov Imre Norbert ${ }^{1}$ \\ Budapesti Müszaki és Gazdaságtudományi Egyetem, Gépészmérnöki Kar, Anyagtu- \\ domány és Technológia Tanszék, 1111, Magyarország, Budapest, Bertalan Lajos ut- \\ ca 7. MT. épület, Telefon+36-1-463-1114 \\ ${ }^{1}$ katona@eik.bme.hu, ${ }^{2}$ szlancsik@eik.bme.hu, ${ }^{3}$ orbulov@eik.bme.hu
}

\begin{abstract}
Metal matrix syntactic foams are applicable on many fields: crash zone parts and protecting shells for aerial vehicles or automotive, vibration damper. Recent work deals with the fracture mechanic testing of ceramic hollow spheres filled A199.5 or AlSi12 matrix syntactic foams. In our study 3-point bending test was used on notched specimens while the notch opening and the bending force were monitored and registered. By the evaluation of the results $K_{Q}$ (under certain conditions $K_{I C}$ ) can be calculated for the investigated materials.
\end{abstract}

Keywords: metal matrix composites, material testing, syntactic foam, fracture mechanics

\section{Összefoglalás}

A fémmátrixú szintaktikus fémhabok számos terülten alkalmazhatóak: légi jármüvek vagy autóipari ütköző zónák energiaelnyelő elemeiként, védőburkolatokként. Jelen kutatómunka kerámia gömbhéjakkal töltött A199,5 és AlSi12 mátrixú szintaktikus fémhabok törésmechanikai méréstechnikájával foglalkozik. Munkánk során bemetszett próbatesteket vetettünk alá 3-pontos hajlító vizsgálatnak, amelyből repedéskinyílás-nyomóerö görbéket kaptunk. Az eredményeket kiértékelve $K_{Q}$ (bizonyos feltételekkel $K_{I C}$ ) meghatározható az adott anyagokra.

Kulcsszavak: fémmátrixú kompozit, anyagvizsgálat, szintaktikus fémhab, törésmechanika

\section{Bevezetés}

Hazai és nemzetközi viszonylatban is egyre nagyobb az érdeklődés a különbözö fémmátrixú kompozitok, fémhabok, így a kerámia gömbhéjakkal töltött alumínium mátrixú szintaktikus fémhabok iránt is. Az ilyen anyagokból készülő alkatrészek gyártásához és használatához fontos ismerni az alapanyag minden olyan tulajdonságát (fáradás, repedésterjedés), ami befolyásolhatja az adott szerkezet üzem közbeni és hosszú távú megbízható müködését. Számos szakcikk foglakozik a szintaktikus fémhabok mechanikai vizsgálatával [1], nyomóvizsgálatával [2,3], struktúrájának leképezésével [4]. Ezzel szemben az anyag törésmechanikai és fáradási tulajdonságairól csak kevés szakirodalom lelhetö fel [5-7].

Az előbbieket szem előtt tartva a kutatás fő célkitüzései technikai tisztaságú alumínium, illetve AlSi12 alumínium ötvözet mátrixú vegyesoxid kerámia gömbhéjakkal töltött szintaktikus fémhabok törésmecha- 
nikai jellemezőinek mérése és az eredmények alapján a tervezéshez is fontos határgörbék, mennyiségek meghatározása.

\section{Felhasznált anyagok és mérési módszerek}

A kutatómunka során vizsgált szintaktikus fémhab anyagot a Budapesti Müszaki és Gazdaságtudományi Egyetem, Gépészmérnöki Karán, az Anyagtudomány és Technológia Tanszék Kompozit laborjában állítottuk elő inert gáz (Ar) nyomással segített, folyadék fázisú infiltrálással. Vizsgálatainkhoz két különböző típusú alumínium mátrixot alkalmaztunk: technikai tisztaságú A199,5-t és ötvözött AlSi12-t. A befoglaló anyagok mért kémiai összetételét az 1. táblázat mutatja.

1. táblázat. A vizsgálatokhoz használt mátrix anyagok kémiai összetétele.

\begin{tabular}{|c|c|c|c|c|c|}
\hline \multirow{2}{*}{ Mátrix } & \multicolumn{5}{|c|}{ Összetétel $(\mathrm{t} \%)$} \\
\cline { 2 - 6 } & $\mathrm{Al}$ & $\mathrm{Si}$ & $\mathrm{Fe}$ & $\mathrm{Mg}$ & egyéb \\
\hline A199,5 & 99,5 & 0,1 & 0,1 & - & 0,3 \\
\hline $\begin{array}{c}\text { AlSi1 } \\
2\end{array}$ & 86 & 12,8 & 0,1 & 0,1 & 1,0 \\
\hline
\end{tabular}

A vizsgált szintaktikus fémhabokban töltőanyagként a Hollomet GmbH Globocer típusú vegyesoxid kerámia gömbhéjait használtuk. Az alkalmazott töltőanyag kémiai összetétele a 2. táblázatban, főbb geometriai méretei pedig a 3. táblázatban találhatóak.

A törésmechanikai mérést, vagyis az anyag repedésterjedési érzékenységét bemetszett próbatesten 3-pontos hajlító vizsgálattal hajtottuk végre. A mérés közben regisztráltuk a terhelő hajlítóerőt a repedéskinyílás függvényében.

2. táblázat. Az alkalmazott töltöanyag kémiai összetétele.

\begin{tabular}{|c|c|c|c|}
\hline \multirow{3}{*}{ Típus } & \multicolumn{3}{|c|}{ Összetétel $(\mathrm{t} \%)$} \\
\cline { 2 - 4 } & $\mathrm{Al}_{2} \mathrm{O}_{3}$ & $\begin{array}{c}\text { amorf } \\
\mathrm{SiO}_{2}\end{array}$ & $\begin{array}{c}\text { mullite } \\
\left(\mathrm{Al}_{2} \mathrm{O}_{3} \cdot \mathrm{SiO}_{2}\right)\end{array}$ \\
\hline Globocer & 33 & 48 & 19 \\
\hline
\end{tabular}

3. táblázat. Az alkalmazott töltőanyag geometriai méretei.

\begin{tabular}{|c|c|c|}
\hline Típus & $\begin{array}{c}\text { Átmérő } \\
(\mu \mathrm{m})\end{array}$ & $\begin{array}{c}\text { Falvastagság } \\
(\mu \mathrm{m})\end{array}$ \\
\hline Globocer & $1450 \pm 83$ & $58 \pm 5$ \\
\hline
\end{tabular}

Elözetes méréseinkhez egy $W=25 \mathrm{~mm}$ magasságú $B=W / 2$ szélességú és $S=4 W$ alátámasztású bemetszett próbatestet alkalmaztunk, a bemetszés sugara $0,25 \mathrm{~mm}$ volt. (1. ábra). A minta nem volt előfárasztva.

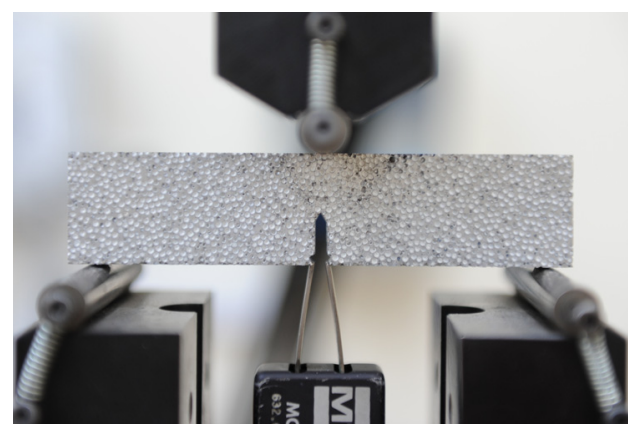

1. ábra. A vizsgált anyag 3-pontos hajlitó vizsgálata bemetszett próbatesten, mérési elrendezés.

Megfigyeltük, hogy a próbatest csak a bemetszett régió közvetlen közelében szenved alakváltozást, illetve károsodást. Ezt szem előtt tartva létrehoztunk egy készüléket, amely segítségével elegendő egy jóval kisebb fémhab anyagrészt vizsgálni (2. ábra). Ez gazdaságosabbá teszi a mérést, mivel egységnyi anyagmennyiségből jóval több próbatest hozható létre, így nagyobb mintaszám érhető el. A kisebb méretủ próbatest szintén $W=25 \mathrm{~mm}$ magassággal $B=\mathrm{W} / 2$ szélességgel és $S=4 W$ alátámasztással rendelkezett. Az $a$ repedéshossz minden minta esetében $12 \mathrm{~mm}$ volt. A kutatómunka során mindkét mátrixanyagú mintából 4-4 próbatestet vizsgáltunk. 


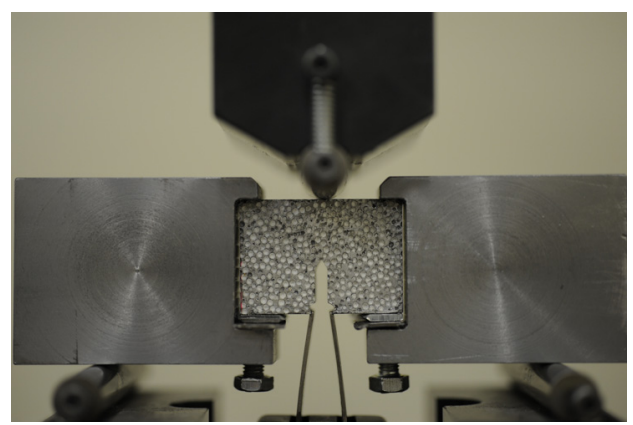

2. ábra. A készülékbe helyezett bemetszett fémhab darab a 3-pontos hajlitó vizsgálatához, mérési elrendezés.

A hajlító vizsgálatok közben a próbatestekről nagyfelbontású képeket készítettünk diszkrét időközönként. Ezen felül a töretfelületet optikai sztereo mikroszkóp segítségével vizsgáltuk meg a méréseket követően.

\section{Eredmények}

A nagyfelbontású képeket elemezve világosan megfigyelhetö, hogy a repedés terjedés irányát az anyagban lévő gömbhéjak drasztikusan befolyásolják. A repedés jellemzően a gömbhéjak mellett, a mátrix anyagban terjed, azonban bizonyos esetben a gömbhéjakon keresztül megy. A különböző mátrixanyagú mintákban a repedés irányában megfigyelhető gömbhéj állapotokat a 4. táblázat mutatja. A repedés síkja esetenként jelentősen kilépett a bemetszés síkjából (3. ábra).

4. táblázat. A vizsgált töretfelületeken található különbözö állapotú gömbhéjak mennyisége a különbözö mátrixanyagú minták esetében.

\begin{tabular}{|c|c|c|c|}
\hline \multirow{2}{*}{ Mátrix } & \multicolumn{3}{|c|}{ Gömbhéj (\%) } \\
\cline { 2 - 4 } & Ép & Törött & Kiesett \\
\hline A199.5 & 63 & 16 & 21 \\
\hline AlSi12 & 27 & 70 & 3 \\
\hline
\end{tabular}

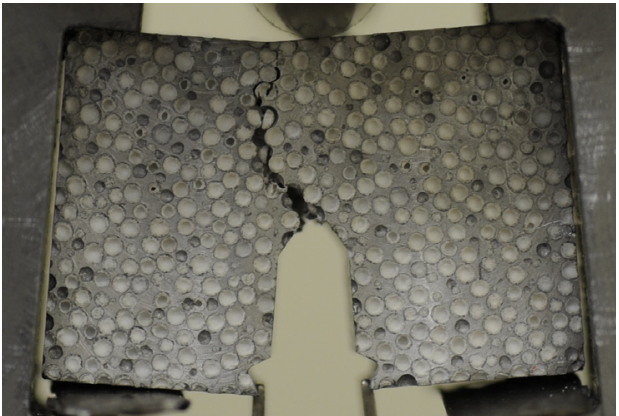

3. ábra. Mérés közbeni felvétel az AlSi12-2 jelü mintáról.

Látható, hogy az ipari tisztaságú alumínium mátrix esetében a gömbhéjak túlnyomó része ép maradt és közel ötöde kiesett. Ezzel szemben a szilíciummal ötvözött mátrixú mintáknál a kiesett gömbhéjak aránya minimális, viszont a töretfelületen vizsgált gömbhéjak túlnyomórésze eltört. Ezek a különbségek a kerámia gömbhéjak mátrix anyaghoz való eltérő kapcsolódása miatt lehetséges.

A hajlító vizsgálatok eredményeként megkaptuk a repedéskinyílás függvényében a nyomóerőt, a különböző mátrixanyagú szintaktikus fémhab próbatestek esetében (4. és 5. ábra). Megfigyelhető, hogy mind az A199,5 és mind az AlSi12 mátrixanyagú minták esetében vannak kiugró értékek, amely jelenség a vizsgált minták struktúrájára vezethető vissza.

A görbék alapján meghatározhatóak a próbatestekre jellemző $K_{Q}$ feszültségintenzitási tényezők értékei. Ennek első lépése, hogy a görbék kezdeti szakaszára illesztett egyenes meredekségét 5\%-al csökkentjük. Ennek az egyenesnek az eredeti görbével vett metszéspontja mutatja meg az ún. $F_{Q}$ erő értékét. Ennek, valamint a próbatest geometriai méreteinek ismeretében az (1) összefüggés alapján meghatározhatók a $K_{Q}$ értékek (5. táblázat). 


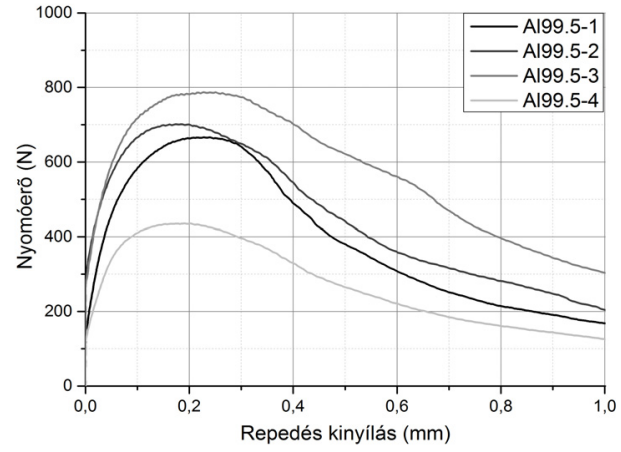

4. ábra. A 3-pontos hajlitó vizsgálatokból kapott nyomóerö-repedéskinyilás görbék az Al99,5 mátrixanyagú minták esetében

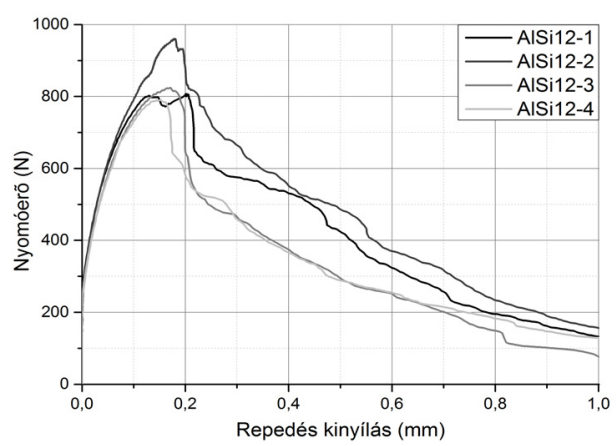

5. ábra. A 3-pontos hajlitó vizsgálatokból kapott nyomóerö-repedéskinyilás görbék az AlSi12 mátrixanyagú minták esetében

$$
K_{Q}=\frac{F_{Q} S}{B W^{\frac{3}{2}}} \cdot g\left(\frac{a}{W}\right)
$$

Ahol g(a/W) csak a geometriától függő alaktényező. Megfigyelhető, hogy különböző mátrixanyagú minták esetében (átlagosan) nagy eltérés van a $K_{Q}$ értékek között, amely az eltérő alapanyag miatt jelentkezik. Fontos megemlíteni, hogy ezek az értékek még nem anyagjellemzők, azok meghatározásához további mérések szükségesek.
5. táblázat. A mérések alapján meghatározható $F_{Q}$ értékek átlaga, valamint az ezekböl számitható $K_{Q}$ értékek átlaga.

\begin{tabular}{|c|c|c|}
\hline Mátrix & $\mathrm{F}_{\mathrm{Q}}(\mathrm{N})$ & $\mathrm{K}_{\mathrm{Q}}\left(\mathrm{N} / \mathrm{mm}^{3 / 2}\right)$ \\
\hline $\mathrm{A} 199,5$ & $483 \pm 128$ & $115 \pm 30$ \\
\hline $\mathrm{A} 1 \mathrm{Si} 12$ & $711 \pm 126$ & $165 \pm 31$ \\
\hline
\end{tabular}

\section{Köszönetnyilvánítás} ÚNKP-16-3-I. KÓDSZÁMÚ Ú NEMZETI KIVÁLÓSÁG PROGRAMJÁNAK TÁMOGATÁSÁVAL KÉSZÜLT"

\section{Szakirodalmi hivatkozások}

[1] Taherishargh M, Belova IV et al.: On the mechanical properties of heat-treated expanded perlite-aluminium syntactic foam. Mater Des. 2014;63:375-83.

[2] Fiedler T, Taherishargh M, et al.: Dynamic compressive loading of expanded perlitelaluminum syntactic foam. Mater Sci Eng A 2015;626:296-304.

[3] Orbulov I.N., Ginsztler J.: Compressive characteristics of metal matrix syntactic foams. Composites Part A, 2012;43(4):55361.

[4] Varga T.A., Mankovits T.: Fémhabstruktúrák elemzése és geometriai modellezése. Müszaki és Menedzsment Tudományi Közlemények 1 2016:2:145-152.

[5] E. Combaz, A. Mortensen: Fracture toughness of Al replicated foam. Acta Materialia, 2010;58:4590-4603.

[6] Katona B., Szebényi G. et al.:Fatigue properties of ceramic hollow sphere filled aluminium matrix syntactic foams. Materials Science and Engineering A-Structural Materials Properties Microstructure and Processing, 2017, 679C:350-357.

[7] M. Taherishargh, B. Katona et al.: Fatigue properties of expanded perlite/aluminum syntactic foams. Journal of Composite Materials, 2016:1-9. 